\title{
Relationship of Damage Causes and Ceiling Damage Levels in Indonesia Hospital
}

\author{
Rita Laksmitasari Rahayu, ${ }^{1, *}$, Sugeng Triyadi $S^{2}$, Lily Tambunan ${ }^{2}$ \\ ${ }^{1}$ Architectural Doctoral Study Program, SAPPK, Bandung Institute of Technology, Indonesia \\ ${ }^{2}$ School of Architecture, Planning and Policy Development, Bandung Institute of Technology, Indonesia
}

Received October 9, 2021; Revised November 26, 2021; Accepted December 13, 2021

\section{Cite This Paper in the following Citation Styles}

(a): [1] Rita Laksmitasari Rahayu, Sugeng Triyadi S, Lily Tambunan, "Relationship of Damage Causes and Ceiling Damage Levels in Indonesia Hospital," Civil Engineering and Architecture, Vol. 10, No. 1, pp. 163 - 174, 2022. DOI: 10.13189/cea.2022.100115.

(b): Rita Laksmitasari Rahayu, Sugeng Triyadi S, Lily Tambunan (2022). Relationship of Damage Causes and Ceiling Damage Levels in Indonesia Hospital. Civil Engineering and Architecture, 10(1), 163 - 174. DOI: 10.13189/cea.2022.100115.

Copyright $\mathrm{C} 2022$ by authors, all rights reserved. Authors agree that this article remains permanently open access under the terms of the Creative Commons Attribution License 4.0 International License

\begin{abstract}
Hospitals are vital buildings that must always be guaranteed the building's resistance to earthquakes. The building must not suffer damage that endangers the safety of the lives of its users. The ceiling is one of the components of a hospital building that is most vulnerable to damage during an earthquake. The patient is not able to escape quickly, if the ceiling material is released and falls on the patient who is below it. This study aims to determine the relationship between the causes of ceiling damage and the level of ceiling damage in hospital buildings. Data were collected through field observations at 3 regional general hospitals and literature studies with relevant topics published in the period December 2017 to January 2021. From the literature review, 39 damage data were obtained in 28 regional general hospital buildings in Indonesia. Data were analyzed using quantitative research methods. From the result, there is a significant relationship between the level of damage to the ceiling and the cause of the damage. Seepage of water is the dominant cause of damage but earthquakes is the cause of fatal damage.
\end{abstract}

Keywords Ceiling, Damage Level, Earthquake, Hospital

\section{Introduction}

The hospital is the important health facilities. Hospitals must remain safe, easily accessible, and function optimally under any conditions, both normal and in conditions affected by earthquakes or emergencies [1]. Hospitals must have disaster mitigation values and be able to perform essential services such as inpatient, outpatient, laboratory, and others. For this reason, it is necessary to build a safe, sturdy, and strong building so that the building can save the lives of medical personnel and patients. Hospitals in Indonesia as primary health facilities are intended for the community. The function of the hospital is to provide medical services - brief, consultative diagnostic, and emergency medical services by professionals and supported by sophisticated equipment [2].

A strong Hospital building also protects assets (equipment and buildings) to function properly. These health facilities must be physically resilient and able to remain operational and continue to provide vital health services after a disaster to ensure immediate medical care [3]. When an earthquake occurs, the hospital is one of the first units whose efficient and timely service can be important and decisive in reducing deaths and rescuing the injured [4].

Hospital buildings in Indonesia have suffered a lot of damage even though they were not affected by the earthquake. Several factors causing building damage are natural factors, mechanical factors, and implementation factors [5]. Damage to hospital buildings occurs in architectural components, namely ceilings, doors, windows, walls, and floor coverings. Damage to 
architectural components can cause hospitals to work optimally, and even endanger the safety of the lives of health workers and patients. The durability of architectural components becomes very important. When an earthquake occurs, the components of the hospital building are more susceptible to damage. Then the architectural components must be resistant to earthquake shocks. Identification of damage needs to be done to know the level of damage and as a recommendation to get a solution.

Damage to the ceiling that occurs in the inpatient room has the risk of causing fatalities because the detached ceiling material will fall on the patient under it. The ceiling is one of the components of a hospital building that is most vulnerable to damage during an earthquake.

The scope of this research is the identification of damage to architectural components - ceiling of regional general hospitals in Indonesia. How is the ceiling damage in hospitals with various causes? The purpose of this study was to find a relationship between the causes of damage and the level of damage to the ceiling in hospitals in Indonesia. The hypothesis of this research is that there is a relationship between the cause of the damage and the level of damage to the ceiling. The cause of ceiling damage due to the earthquake had a major impact on the safety of the lives of patients and health workers.

Hospitals in Indonesia consist of several classes according to the completeness of their services, ranging from class D to class A. Hospital management is in accordance with hospital ownership, namely government or private. The local government manages the Regional General Hospital as a health facility that serves the community in its area. The quality of hospital services can serve with a complete level. Regional General Hospitals use a referral system. Referrals to Regional General Hospitals are a delegation of reciprocal responsibilities from other public hospitals both vertically and horizontally [6].

Class B Regional General Hospital serves the community in districts and cities in Indonesia. Class B hospitals are also referred to from lower class hospitals, namely class $\mathrm{C}$ and class $\mathrm{D}$. One of the important installations at the Regional General Hospital is the inpatient installation. Class B Regional General Hospital has a minimum of 250 beds [7].

\subsection{Architectural Elements-Ceiling}

In addition to endangering lives, damage to ceiling architectural components costs a lot of money and to repair requires a lot of time. Hospital functional failure is not structural damage but the hospital's inability to function during an emergency. Architectural components consist of ceilings, windows, and doors [8].

Architectural components are included in the Operational and Functional Components (OFC) category, which differ from one building type to another. The function, the design of the building, the country in which the building stands are what distinguishes OFC. This is because there are differences in construction practices and local construction industry standards. Each country should develop its own OFC for different buildings and identify the appropriate aseismic approach for its own needs [9].

Ceiling as one of the important architectural components in a space. Ceiling must be strong and sturdy in post-disaster conditions and moreover under normal conditions. The architectural components of the ceiling must be firmly installed and not subject to physical changes or damage so that they can guarantee the safety of the people under them. Moreover, the safety of patients in inpatient rooms who have limited mobility for self-rescue. Damage to architectural components is dangerous for people and equipment that are nearby [10]. Falling ceilings can fall and injure people and can block access in critical areas [11].

Buildings that stand and operate normally, suddenly become damaged and even collapse and cannot operate normally. When an earthquake occurs, the structural elements in the building act on the reaction (earthquake force). This condition affects several architectural components. One of the architectural components that is strongly influenced by the performance of the structural elements of the building is the ceiling. The ceiling cover was damaged starting from coming off and still hanging on the ceiling frame. Alternatively, the ceiling covering, and ceiling truss fell and hit the patient below. The occurrence of a very fast earthquake and damaged ceiling architectural components resulted in inpatients being unable to save themselves.

Ceiling architectural components are part of non-structural elements that need to be planned so that they are strong in all conditions. Ceiling construction must have good durability. The ceiling in the hospital building was damaged a lot with the lowest level of damage to the level of severe damage. The level of damage is low to moderate causing the ceiling to suffer a severe level of damage if the ceiling of the building is hit by an earthquake. The durability of the ceiling during an earthquake is not guaranteed for the safety of the patient's life. The cause of the level of damage to the ceiling in hospitals is caused by water seepage, poor quality of building materials, construction failures, and earthquakes. Ceiling damage occurs throughout the life of the building.

The decline in the quality of the building materials used can result in damage to the construction. Buildings using building materials that are not good or not in accordance with the standards and calculations of building experts cause building failure. One of the construction failures is due to lack of supervision during the construction work. Civil engineers as building experts are responsible for the strength of the building and the quality of the building materials used [12].

The regular shape of the building mass (geometry) will 
increase the strength and stiffness of the building in responding to earthquake forces. When a building has an irregular shape, such as asymmetry or vertical discontinuity, the assumptions used in developing seismic criteria for buildings with regular shapes may not apply [13]. The vertical irregular shape of the building is prone to earthquakes in earthquake-prone areas. Buildings are designed by combining structure and aesthetics effectively, especially for irregular buildings [14].

The behavior of building structural elements when the building experiences ground movement or earthquake, that is, each structural element experiences lateral displacement and deformation. Lateral displacement and deformation change according to the level of response of the structure to the movement of the ground beneath it. The higher the level of response to lateral displacement, the point of deformation of the element will reach even beyond the elastic or inelastic linear capacity. In this condition the building will be damaged. Multi-storey buildings experience shear deformation and bending deformation. Limitation of lateral displacement due to ground movement (earthquake) according to the level of ongoing damage and performance objectives of the building function [15].

Drops of water on the ceiling cause mold on the surface of the ceiling. Fungus on the surface of the ceiling covering is fungal colonization because of relatively high relative humidity (RH) which results in the adsorption of water vapor from the air [16]. Fungal growth depends on the specified relative humidity $(\mathrm{RH})$ value, flow velocity air and temperature on porous materials [17]. Ceilings are often damaged due to seepage and leaks in the roof area then water falls on the ceiling covering. If the ceiling covering is made of gypsum, then the building materials will blacken on the gypsum surface and are easily weathered [5].

Damage to buildings is influenced by time (time dependent). Factors affecting the damage to buildings are a decrease in the quality of building materials. External forces or internal forces (moments, stresses, strains) acting on structural elements throughout the life of the building. These conditions affect the level of damage to the building. The external style will also affect the age of the building. The influence of weather causes decarbonation. Likewise, earthquake forces affect damage to buildings [18].

\subsection{Ceiling Damage in the Regional General Hospital}

Architectural and furnishing is one of the indicators of a hospital that is safe against disasters. Architectural and furnishing indicators consist of safety of roofing and ceiling, safety of doors and windows, safety of walls, divisions, and partitions, safety of floor coverings [19]. Some examples of ceiling damage in hospitals, namely the fall of the ceiling cover, lack of ties to the ceiling frame, and damage due to other components that depend on ceiling construction $[20,21]$. Ceiling construction is a strong unified system so that the panels and hangers do not move when an earthquake occurs. For that we need the right reinforcement so that the ceiling is resistant to earthquake loads [21].

Each building considers a performance-based approach to the effects of various possible disasters. Hospitals are buildings that take into account the performance level of direct occupancy of buildings (immediate occupancy approach), which is a condition where after a disaster the structure is still safe with only minor minor damage which to repair it does not interfere with the user, the strength and stiffness are almost the same as the conditions before the disaster, the system the vertical and lateral forces on the structure are still able to bear the earthquake forces that occur.

\subsection{Damage Level}

Measurement of the level of damage using the European Macroseismic Scale (EMS). In Table 1, the assumed level of damage to EMS consists of five levels, namely 1-5. between structural damage to buildings affects non-structural damage to buildings. At the level of damage 1, the building did not suffer structural damage, but the building suffered minor non-structural damage. Damage level 4 includes very heavy damage, where the building suffered heavy structural damage and the building suffered very heavy non-structural damage [22].

Table 1. Definition of damage level

\begin{tabular}{|c|l|l|}
\hline $\begin{array}{c}\text { Damage } \\
\text { Level } \boldsymbol{L}_{\boldsymbol{d}}\end{array}$ & \multicolumn{1}{|c|}{ Definition } & \multicolumn{1}{c|}{ Notes } \\
\hline 0 & No damage & - \\
\hline 1 & Slight damage & No SD, slight N-SD \\
\hline 2 & Moderate damage & $\begin{array}{l}\text { Slight SD, Moderate } \\
\text { N-SD }\end{array}$ \\
\hline 3 & $\begin{array}{l}\text { Substantial to heavy } \\
\text { damage }\end{array}$ & $\begin{array}{l}\text { Moderate SD, heavy } \\
\text { N-SD }\end{array}$ \\
\hline 4 & Very heavy damage & $\begin{array}{l}\text { Heavy SD, very heavy } \\
\text { N-SD }\end{array}$ \\
\hline 5 & Destruction & Very heavy SD \\
\hline SD $=$ Structural Damage; N-SD $=$ Non-Structural Damage \\
\hline
\end{tabular}

\section{Materials and Methods}

\subsection{Research Method}

This study uses quantitative research methods. Data collection at the field observation stage and literature study to search for keywords Keyword discovery from newspaper analysis is often used in research on social phenomena [23,24] and is used in newspaper discourse analysis research [25]. The explanation of everything with a language approach is included in the newspaper analysis stage. From social research, this stage is carried out by individuals and social groups who are marginalized and 
oppressed in it [26].

Some key words from newspaper studies and field observations as initial meaning. The keyword group is the category (content analysis). This stage is included in the initial meaning that uses the researcher's meaning [27]. The discovery of keywords in newspapers or mass media can be said to be significant if one newspaper is found to be used 20 times and there are two uses of the same word in different newspapers [28]. Open coding was performed as part of the content analysis. At the open coding stage, keywords are used from existing text data.

\subsubsection{Data Collection}

Data collection is focused on Regional General Hospitals in Indonesia which have damage to the ceiling. Data collection methods used interview techniques, field observations, literature studies, and archives. Field observations were carried out in 3 hospitals and a literature review was conducted in 25 hospitals in Indonesia through several reputable online national news articles. From 25 articles in the information media, it is explained that the ceiling elements of architectural components are often damaged.

Collecting data using archival study techniques and field studies (observations and interviews). The nature of data collection is open, which aims to capture all the unexpected or unexpected possibilities. Flexible data collection by following the development of incoming data. Incoming data correspond to the scope. The amount of data collected is as much as possible until it is saturated. This data collection time is from December 2017 to January 2021.

Literature studies and preliminary observations were carried out to explore the complete field data. The literature study uses visual identification techniques from photographs in journals and media. The data are taken from valid national mass media which have been published constantly for a long time and without drastic editorial changes. In addition, online mass media has a certain orientation to the number of readers, and status [29]. The hospital literature study data collected were the names of local and national online mass media, news links, writers/editors, the name of the hospital, the city where the hospital was founded, when the damage occurred, sources in the news, types of ceiling damage, photos, location of damage such as installations, hospitalization, Emergency Unit, and others. All damage information is interpreted according to the photo in the news article.

The interview technique was used in field observations. The scope of questions at the building maintenance and development stage is aimed at the hospital household and hospital infrastructure and facilities installation officers. Interviews were conducted by asking open-ended questions, then memos were made to obtain important keywords.

\subsubsection{Data Analysis Steps}

The results of the first step are entered as input in the second step. The method used in the second step is the correspondence between the variable level of damage and the cause of the damage. The result of the second step is the relationship between the level of damage and the cause of each factor causing damage to the ceiling. After the researchers conducted content analysis, the researchers then carried out distribution analysis and correspondence analysis [30].

Keywords "collapsing ceiling cover", "bathroom water seepage", and "the use of building materials that are not according to specifications", and others are the result of open coding. Qualitative research at the content analysis step can enrich information about the type of damage, the cause of the damage, and the location of the damage. The second step uses distribution analysis to determine the number or percentage of damage locations, types of damage, and causes of damage. Next is the correspondence analysis to see the relationship between the cause of the damage and the level of damage (Figure 1).

\subsection{Research Area and Sample Selection}

The literature review comes from several online national media news articles, such as Okezone, Liputan 6, Tribune News, Kompas, Sindo, and others. Online national media reported the ceiling damage that occurred at the Regional General Hospital. There are 25 Regional General Hospitals reported such as Sinjai-South Sulawesi, Bima-West Nusa Tenggara, Jailolo-Halmahera, Datu Beru Tangkengon-Aceh, Bangli-Bali, Pringsewu Lampung, Blora-Central Java, Ngawi-East Java, Cirebon-Java West, Blitar-East Java, Malingping-Banten, Lebak-Banten, Lamongan, South Halmahera Labuha, Mamuju-West Sulawesi, and Majene-West Sulawesi.

Field observations were carried out at Dr Soekardjo Hospital in Tasikmalaya City, Dr Slamet Hospital in Garut City, and Mardi Waluyo Hospital in Blitar City. The cities of Tasikmalaya and Garut are in the province of West Java, while the city of Blitar is in the province of East Java. The three hospitals are in the south of Java Island and are in earthquake-prone areas. The strength of the earthquake causes swaying of the building structure. The shaking can cause damage to the building. The magnitude of the value of the mapped earthquake acceleration and the amplification value of the spectral acceleration on the ground surface [30] affect the calculation of the strength of the building against the earthquake. Hospital ceiling construction must be strong before the building is hit by an earthquake. The vulnerability of the ceiling construction can override the patient below it. 




Figure 1. Research steps

\section{Results and Discussion}

\subsection{Result}

Researchers get categories for the location of the damage, the type of damage, the cause of the damage. The level of damage to the ceiling is taken from the level of damage to the building based on EMS.

\subsubsection{Location of Damage}

Ceiling damage was found in several locations, as keywords, namely "Emergency Unit", "inpatient room lobby", "hemodialysis", "radiology", "lobby", "Intensive Care Unit (ICU)", "pharmacy room". Categories were obtained from grouping keywords according to the regulation of the Minister of Health of the Republic of Indonesia No. 56 of 2014. In Table 2, the categories of the keyword groups are emergency medical services for emergency units, clinical support services for hemodialysis and radiology, pharmaceutical services, medical services, non-clinical support for the lobby, specialist medical services for outpatient units, inpatient services for inpatient corridors and inpatient rooms. Damage very often (72\%) occurs in inpatient services. Medical support services, emergency services, non-clinical support services are rare $(8 \%)$. Pharmaceutical services are very rare $(3 \%)$ of ceiling damage (Figure 2). damage location

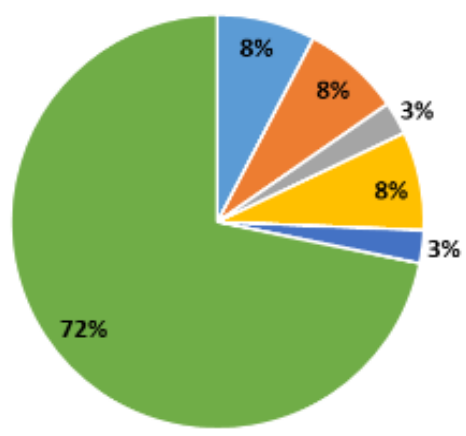

$$
\begin{array}{ll}
\text { m emergency medical services } & \text { m clinical support services } \\
\text { = pharmaceutical service } & \text { " non-clinical support services } \\
\text { m specialist medical services } & \text { m inpatient service }
\end{array}
$$

Figure 2. Location of ceiling damage

Table 2. Categories and keywords for location of ceiling damage

\begin{tabular}{|c|l|l|}
\hline No & \multicolumn{1}{|c|}{ Category } & \multicolumn{1}{c|}{ Keywords } \\
\hline \multirow{2}{*}{1} & inpatient service & inpatient \\
\cline { 3 - 3 } & & inpatient corridor \\
\hline \multirow{2}{*}{2} & \multirow{2}{*}{ clinical support services } & hemodialysis \\
\cline { 3 - 3 } & & radiology \\
\cline { 3 - 3 } & & Intensive Care Unit \\
\hline 4 & pharmaceutical service & pharmacy \\
\hline 5 & emergency medical services & emergency unit \\
\hline
\end{tabular}


Ceiling damage in inpatient services dominates the location of damage compared to other service units. Patients are limited to moving to save themselves when the earthquake occurs. Earthquake events when the patient is unable to save himself, in addition to having a psychological impact is also very dangerous for life safety.

\subsubsection{Damage at Regional General Hospital}

Table 3. Categories and keywords for types of ceiling damage

\begin{tabular}{|c|c|c|}
\hline No & Category & Keywords \\
\hline \multirow[b]{2}{*}{1} & \multirow{2}{*}{$\begin{array}{l}\text { black spots on the } \\
\text { ceiling covering }\end{array}$} & weathered ceiling covering \\
\hline & & $\begin{array}{l}\text { black spots on the ceiling } \\
\text { covering }\end{array}$ \\
\hline 2 & $\begin{array}{l}\text { deformed ceiling } \\
\text { covering }\end{array}$ & $\begin{array}{l}\text { deformation of the ceiling } \\
\text { covering }\end{array}$ \\
\hline 3 & $\begin{array}{l}\text { the ceiling cover } \\
\text { came off and fell }\end{array}$ & collapsed ceiling cover \\
\hline \multirow{2}{*}{4} & \multirow{2}{*}{ loose ceiling frame } & loose and hanging ceiling frames \\
\hline & & ceiling frame loose and fall \\
\hline
\end{tabular}

Several keywords for types of ceiling damage obtained from online national mass media and field observations, namely weathered ceiling covers, black spots on ceiling coverings, collapsed ceiling covers, curved ceiling covers, loose and hanging ceiling frames, and loose and falling ceiling frames. Keywords are grouped into several categories, namely weathered ceiling covers, curved ceiling covers, collapsed ceiling covers, loose ceiling frames (Table 3).

In Figure 3, the type of damage to the ceiling covering is loose and falling occurs in hospitals $(62 \%)$. Loose ceiling frames occur quite a lot $(28 \%)$. The loose ceiling frame includes the condition of the loose - hanging ceiling frame and the loose - falling ceiling frame. Both conditions are very dangerous for patient safety. The type of damage to the blackened ceiling cover due to mold is $8 \%$. The type of damage to the ceiling covering that experienced bending was $3 \%$.

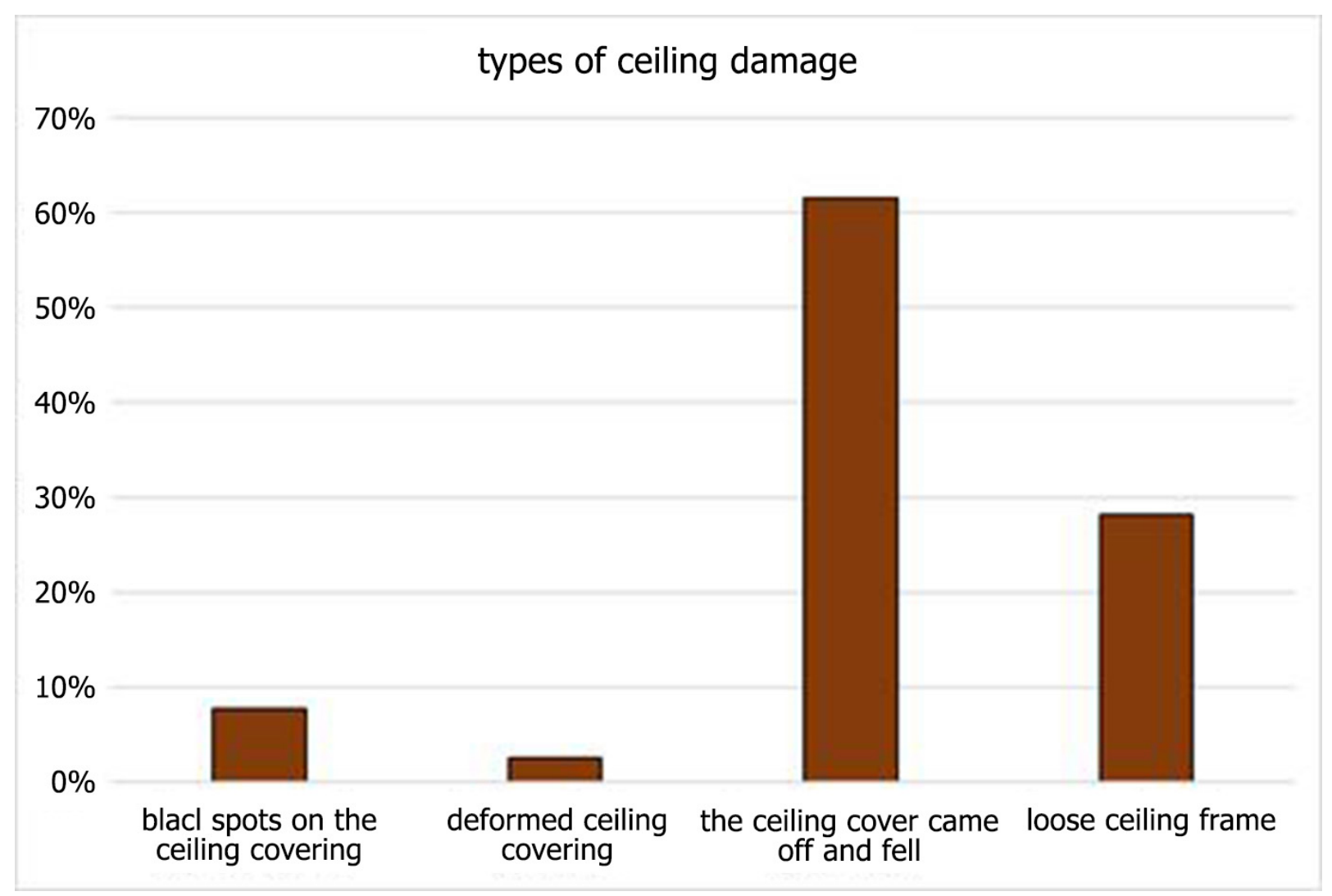

Figure 3. Percentage of types of ceiling damage 


\subsubsection{Causes of Ceiling Damage}

In addition to the type of damage, data on the cause of the damage were also collected. The cause of damage to the ceiling is due to the condition of fragile building materials, seepage of water from the bathroom on the top floor, failure of building construction, building materials that are not in accordance with specifications, roofs that are not able to withstand water loads, rain splashes, and earthquakes. The keywords causing the damage are grouped into categories, namely water seepage, earthquake, decreased quality of building materials, and construction failure. The causes of damage are categorized according to the data held in data collection and literature study. There are several causes of damage including poor quality of building materials, chemical causes, climatic conditions, and building location. Factors causing damage are natural factors, mechanical factors, and implementation factors [32,5]. Damage to the ceiling of the inpatient room, such as blackened ceiling covering due to fungus, damaged ceiling covering (Figure 4).


Figure 4. Ceiling damage photos

The Regional General Hospital uses a reinforced concrete frame structure system. Most the number of floors of a 2-story hospital building (56\%). Hospital buildings have 3 floors as much as $21 \%$ and 4 storey buildings as much as $8 \%$. The number of floors of the Hospital is 2 floors to 4 floors. Most hospitals use aluminum ceiling frames $(82 \%)$ and hospitals use wooden ceiling frames as much as $18 \%$. Regional hospitals use $72 \%$ gypsum ceiling coverings, some hospitals still use $21 \%$ multiplex ceiling coverings, and $8 \%$ other materials.

The observed hospitals have an age range of 1 to 9 years. The age of the hospital is calculated from the time it was built and the old building that has been renovated. The age of the building is calculated from the year of the last inauguration or renovation of the room based on the article. The method of installing the ceiling frame and its cover uses the method commonly used in simple buildings. From the results of interviews with the hospital building technicians studied, the ceiling installation method in the hospital does not have a special installation method.

Some of the keywords that caused the damage were "decreased quality of ceiling materials", "fragile building materials", "ceiling construction errors", "roofs unable to withstand water loads", "water seepage", and "earthquakes". The keywords of "declining quality of ceiling building materials and fragile building materials" are in the category of declining quality of ceiling building materials. "Ceiling construction failures", "ceiling construction errors", and "the roof not being able to withstand the water load" are included in the category of "construction failure and poor ceiling building materials". Seepage category of water seepage keywords. Earthquake category from the keyword earthquake (Table 4).

Table 4. Categories and keywords of the causes of ceiling damage

\begin{tabular}{|c|c|c|}
\hline No & Category & Keywords \\
\hline \multirow{2}{*}{1} & \multirow{2}{*}{$\begin{array}{l}\text { decrease in material } \\
\text { quality }\end{array}$} & decrease in material quality \\
\hline & & brittle building material \\
\hline \multirow{3}{*}{2} & \multirow{3}{*}{$\begin{array}{l}\text { construction failure and } \\
\text { poor materials }\end{array}$} & building construction failure \\
\hline & & ceiling construction error \\
\hline & & $\begin{array}{l}\text { the roof is not able to } \\
\text { withstand the load of water }\end{array}$ \\
\hline 3 & water seepage & water seepage \\
\hline 4 & earthquake & earthquake \\
\hline
\end{tabular}

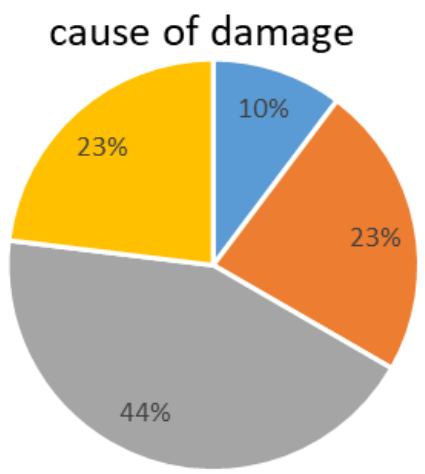
- decrease in material quality $10 \%$
- construction failure and poor materials $23 \%$
- seepage water $44 \%$
- earthquake $23 \%$

Figure 5. Percentage of causes of ceiling damage

Damaged ceilings are caused by several categories of causes of damage, namely "decreased quality of building materials", "water seepage", "earthquakes", and "failure of ceiling construction and poor building materials". Seepage of water as the main cause of damage to the 
ceiling (44\%). The percentage of ceiling damage $23 \%$ was caused by construction failures and poor ceiling materials and earthquakes. The smallest percentage of causes of damage is the decline in the quality of building materials, which is $10 \%$ (Figure 5).

\subsubsection{Ceiling Damage Rate}

Types of damage to the ceiling occur from black spots on the ceiling covering to the ceiling frame falling off and falling. There are 2 types of major damage, namely damage to the ceiling cover and damage to the ceiling frame. Damage to the ceiling cover does not necessarily mean damage to the ceiling frame. But damage to the ceiling frame, automatically damage to the ceiling cover. For this reason, the level of damage to the ceiling can be defined in Table 5. The level of damage 0 describes no damage to either the ceiling cover or the ceiling frame.

Damage level 1 occurs when the ceiling has minor damage to the ceiling covering and there is no damage to the ceiling frame. The ceiling covering is slightly moldy and blackened, it can be replaced without affecting the ceiling frame. The ceiling frame was not damaged. Ceiling frames and frame hangers remain unchanged or deformed. Damage level 2 occurs in ceiling coverings that are moderately damaged. The ceiling cover has come off and some of it is still hanging in position. The ceiling frame was slightly damaged, namely the disconnection between the ceiling frame and the cover. At the level of damage 3 , the ceiling covering is in a severely damaged condition and the ceiling frame is moderately damaged. The ceiling covering is partly hanging off and partly falling off. Some of the ceiling frame connections are not installed properly. If the condition of the entire ceiling cover falls and all the frame hangers are released, including he level of damage 4. The level of damage is very heavy forthe level of damage 4 . Damage level 5 can only be measured for the ceiling frame, including very heavy damage. (Table 5).

The types of damage categories consist of black spots on the ceiling cover, the ceiling cover that is deformed (curved), the ceiling cover comes off and falls off, and the ceiling frame comes off. On the type of damage to black spots on the ceiling covering, including damage level 1, the definition of light damage to the ceiling covering and no damage to the ceiling frame. The type of damage to the ceiling covering was deformed, including the level of damage 2 . The ceiling cover was moderately damaged where some of it was separated from the ceiling frame but there was still a part of the ceiling covering hanging off. The ceiling frame suffered minor damage, some of the joints between the cover and the frame were not connected properly. Types of damage to the ceiling covering falling off and falling, including the level of damage 3. Ceiling construction has severe damage to the ceiling cover and the ceiling frame is moderately damaged. The connection between the ceiling cover and the frame is not well connected. The ceiling covering came off and fell off, but some of the joints in the ceiling joint frame were not attached properly. Ceiling trusses fall and fall including damage level 4 . The ceiling construction suffered heavy cover damage and the frame was heavily damaged (Table 5).

\subsection{Discussion}

In Figure 6, the ceiling experienced a level of damage of $41.7 \%$ because of construction failures and the use of low-quality building materials. The decline in the quality of building materials resulted in the ceiling construction experiencing a damage level of 1 as much as $66.7 \%$. Buildings suffered level 1 damage due to the earthquake, as much as $22.2 \%$. Water seepage is the main cause $(100 \%)$ of damage to level 1 ceiling construction.

Level 2 damage occurred due to construction failure and poor quality of building materials as much as $58.3 \%$. Level 2 damage was also experienced by ceiling construction which was damaged due to a decrease in the quality of building materials, as much as $33.3 \%$. The building did not suffer level 2 damage due to the earthquake. But the earthquake caused damage rate 3 as much as $55.6 \%$. The level of damage 4 was only caused by the earthquake as much as $22.2 \%$. Damage level 3 includes severe damage, where the frame is not installed properly and the ceiling cover is partially hanging off. Damage level 4 includes very heavy damage. The ceiling frame is mostly loose and the entire ceiling cover is off. 
Table 5. Definition of the level of damage according to the category of the cause of the damage

\begin{tabular}{|c|c|c|c|c|}
\hline $\begin{array}{c}\text { damage } \\
\text { level }\end{array}$ & $\begin{array}{l}\text { definition of } \\
\text { damage type }\end{array}$ & $\begin{array}{c}\text { CFD }= \\
\text { Ceiling Frame Damage; }\end{array}$ & $\mathrm{CCD}=$ Ceiling Cover Damage & \\
\hline 1 & $\begin{array}{l}\text { black spots on } \\
\text { the ceiling } \\
\text { covering }\end{array}$ & $\begin{array}{l}\text { there is no damage to the } \\
\text { ceiling frame, the ceiling } \\
\text { frame and frame hangers } \\
\text { remain unchanged }\end{array}$ & $\begin{array}{l}\text { Slight CCD } \\
\text { The ceiling cover is slightly moldy } \\
\text { and blackened, it can be replaced } \\
\text { without affecting the ceiling frame }\end{array}$ & $\begin{array}{l}\text { https://makassar.sindonews.com/read } \\
\text { /305598/713/pasien-rsud-sinjai-panik } \\
\text {-nyaris-tertimpa-plafon-ruang-peraw } \\
\text { atan-1610967686 }\end{array}$ \\
\hline 2 & $\begin{array}{l}\text { deformed } \\
\text { ceiling covering }\end{array}$ & $\begin{array}{l}\text { Slight CFD (connection } \\
\text { between ceiling frame } \\
\text { and cover is removed) }\end{array}$ & $\begin{array}{l}\text { Moderate CCD } \\
\text { The ceiling covering was } \\
\text { moderately damaged where the } \\
\text { ceiling cover came off and some of } \\
\text { it was still hanging in position. }\end{array}$ & $\begin{array}{l}\text { https://www.jawapos.com/jpg-today/0 } \\
\text { 7/04/2018/gedung-rusak-pelayanan-c } \\
\text { uci-darah-rsud-sleman-tersendat/ }\end{array}$ \\
\hline 3 & $\begin{array}{l}\text { the ceiling cover } \\
\text { came off and } \\
\text { fell }\end{array}$ & $\begin{array}{l}\text { Moderate CFD, } \\
\text { some of the connections } \\
\text { are not installed properly. }\end{array}$ & $\begin{array}{l}\text { Heavy CCD } \\
\text { The ceiling cover was partly } \\
\text { hanging and partly falling }\end{array}$ & $\begin{array}{l}\text { https://www.tribunnews.com/regional } \\
\text { /2021/04/11/tiga-ruang-pasien-di-pav } \\
\text { iliun-rsud-mardi-waluyo-blitar-beran } \\
\text { takan-akibat-gempa }\end{array}$ \\
\hline 4 & $\begin{array}{l}\text { loose ceiling } \\
\text { frame }\end{array}$ & $\begin{array}{l}\text { Heavy CCD, } \\
\text { The whole frame and part } \\
\text { of the hanger fell off }\end{array}$ & $\begin{array}{l}\text { Very heavy CCD } \\
\text { The entire ceiling cover fell }\end{array}$ & $\begin{array}{l}\text { https://radarkudus.jawapos.com/read } \\
\text { /2021/01/06/233921/duh-baru-setahu } \\
\text { n-dibangun-plafon-rsud-blora-ambro } \\
\text { l }\end{array}$ \\
\hline
\end{tabular}

Damage level 3 includes a severe level of damage for the ceiling covering and a moderate level of damage for the ceiling frame. Damage level 3, the connectors on the frame are not connected properly and the ceiling cover is partly falling and part hanging. Falling ceiling coverings will endanger the safety of patients and health workers. Similarly, the level of damage 4 caused by the earthquake. Some ceiling frames fall on people below them, especially dangerous for patients with limited mobility. The ceiling frame falls, it can no longer be used as a frame for the ceiling covering. The causes of earthquake damage require special attention.

The dendrogram graph (Figure 7) shows a close relationship between the causes of water seepage damage and damage level 1 (mild). Water seepage has no damage to the ceiling frame but there is minor damage to the ceiling cover. This level of damage does not have the potential to injure patients and health workers. The cause of the deterioration of the quality of building materials is related to water seepage. Damage to the ceiling due to water seepage causes a decrease in the quality of building materials. Ceiling construction failure and poor ceiling building materials are closely related to the level of damage 2 (medium). The ceiling frame construction suffered minor damage and the ceiling covering was moderately damaged. Damage level 2 resulted in the ceiling covering hanging off. The condition does not injure the patient under it but makes the patient uncomfortable.

The cause of earthquake damage has a close relationship with damage level 3 and damage level 4. Most earthquakes cause damage level 3 (severe) in ceiling construction. The ceiling frame construction was not installed properly and part of the ceiling covering fell off. This condition has the potential to injure patients and health workers. 


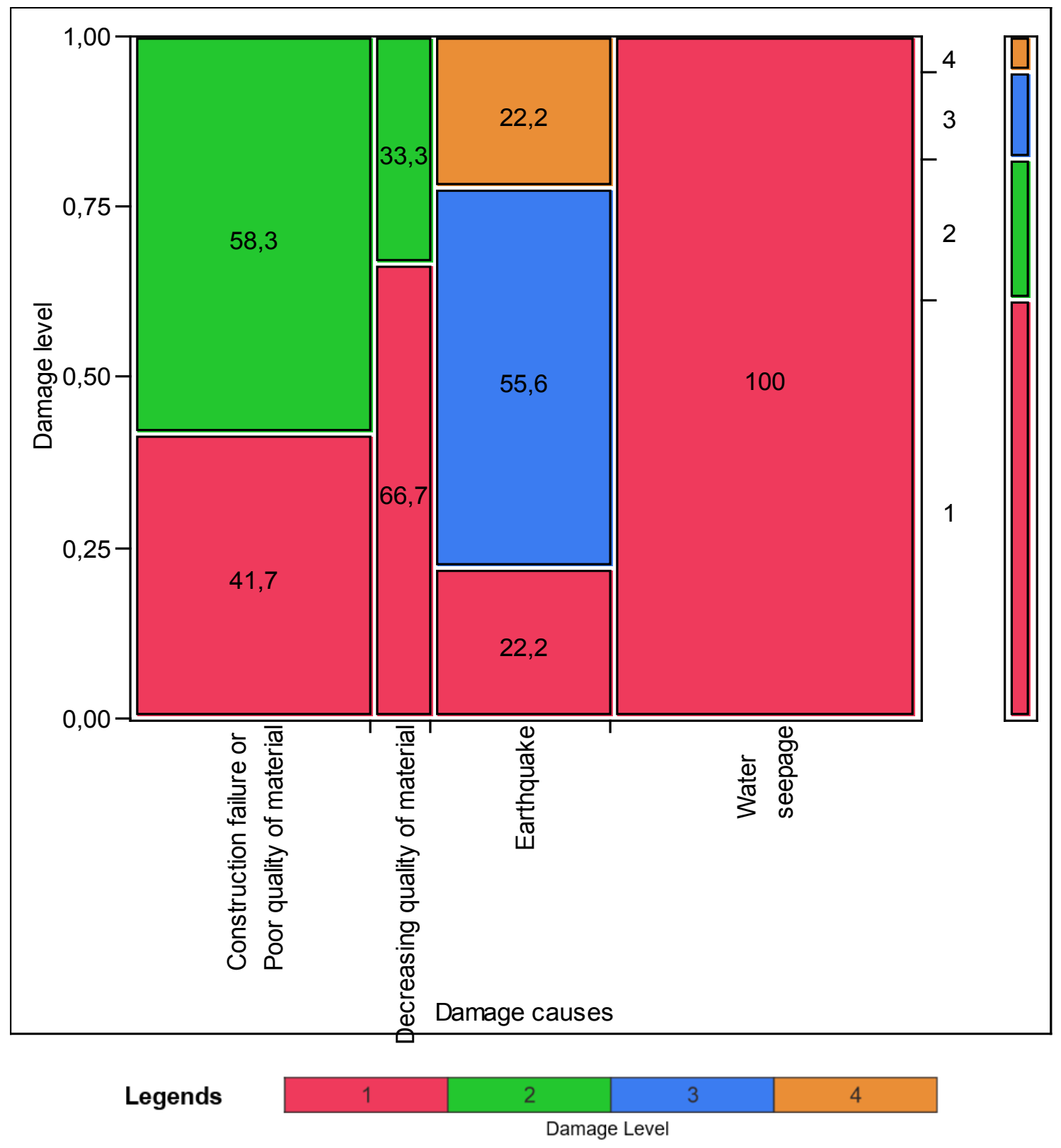

Figure 6. The relationship between the cause of the damage and the damage level

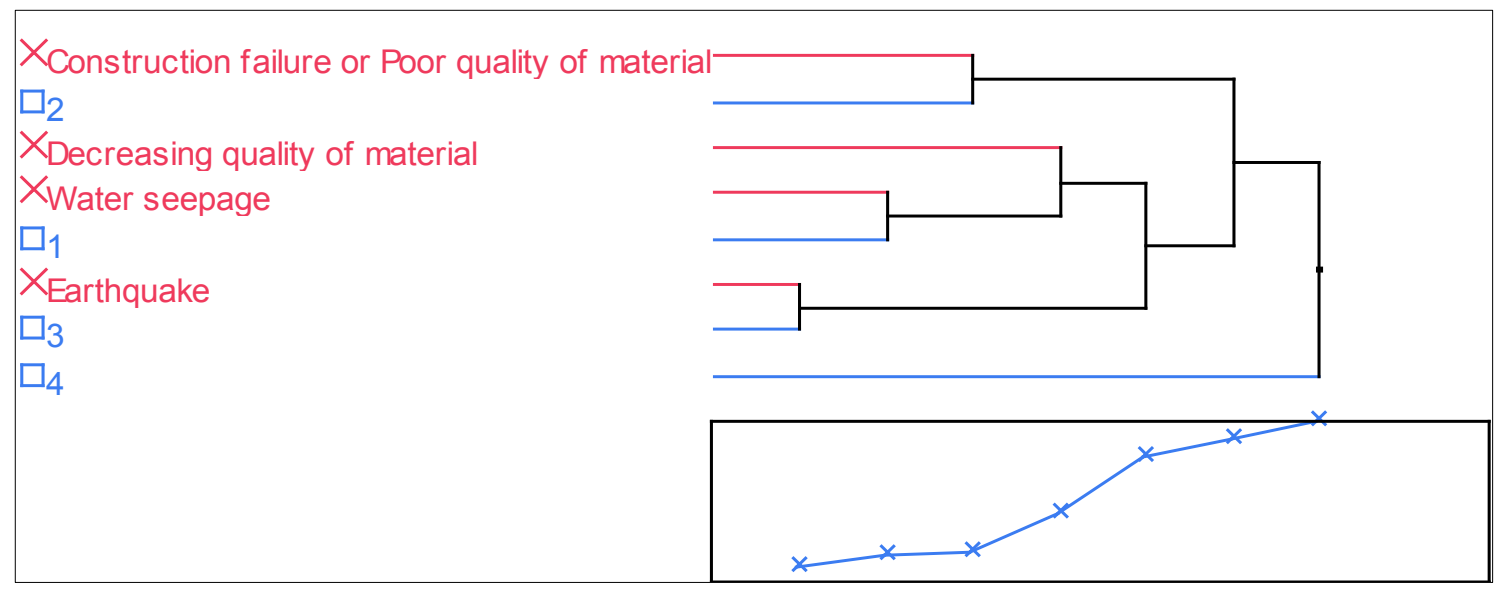

Figure 7. Dendogram graph 


\section{Conclusions}

This research data were collected from a limited number of samples, so the level of reliability is not too high. To get better results regarding the relationship between the causes of ceiling damage and the level of ceiling damage, further research is needed with a larger number of hospitals or research with clear boundaries, such as the age of the building, the number of floors of the building.

Ceiling is often damaged due to water seepage. A damaged ceiling cover due to a leak will reduce the quality of the ceiling material. Ceiling damaged due to water seepage makes the ceiling condition have a frame and hangers that are still strong (damage level 1) but the ceiling cover looks black. This cover can be fixed without affecting the strength of the hanger and the frame. Damage level 1 must be repaired quickly so that it is resistant to other causes of damage such as earthquakes.

Damage level 1 (mild) is dominated by the cause of ceiling damage due to water seepage. Damage level 1 does not cause injury to patients and health workers. The cause of damage due to the earthquake is not the main cause of ceiling damage, but the earthquake can cause damage to the ceiling which is categorized as damage level 3 and damage level 4. As is known, damage level 3 includes the level of severe damage and level 4 damage is included in the category of very heavy damage.

This level of damage can result in injury to hospitalized patients. Earthquakes play a very important role in building damage, especially ceiling architectural components. Earthquake as the cause of fatal ceiling damage. Ceiling construction needs to pay attention to ceiling material specifications, standards, and installation procedures. Before the ceiling frame and ceiling cover are installed, it is necessary to ensure that the ceiling construction is in accordance with existing standards. Designers and project implementers need to pay attention to how the space works so that the space does not experience water seepage.

\section{REFERENCES}

[1] World Health Organization. Regional Office for the Western Pacific, "Safe hospitals in emergencies and disasters : structural, non-structural and functional indicators" WHO Regional Office for the Western Pacific, 2010, https://apps.who.int/iris/handle/10665/207689

[2] Irina Bulakh, Olena Chala, Viktor Divak, "Dynamics of Architectural and Urban Planning Hospital Systems Evolution" Civil Engineering and Architecture 8(4), 2020, pp 586-598, DOI: 10.13189/cea.2020.080423

[3] Nebil Achour, Masakatsu Miyajima, Masaru Kitaura, and Andrew Price, "Earthquake-Induced Structural and
Nonstructural Damage in Hospitals.” Earthquake Spectra, Vol. 27, No. 3, Aug. 2011, pp. 617-634, https://doi.org/10.1193/1.3604815

[4] Esmail Heidaranlu; Hamidreza Khankeh; Abbas Ebadi; Ali Ardalan. "An Evaluation of Non-Structural Vulnerabilities of Hospitals Involved in the 2012 East Azerbaijan Earthquake". Trauma Monthly, 22, 2, 2017, -. doi: 10.5812/traumamon. 28590

[5] Arief Subakti Ariyanto, "Analisis Jenis Kerusakan Pada Bangunan Gedung Bertingkat (Studi Kasus pada Gedung Apartemen dan Hotel Candiland Semarang)", Bangun Rekaprima Vol.06, No 1, pp. 45-57, 2020. http://dx.doi.org/10.32497/bangunrekaprima.v6i1,\%20Apri 1.1929

[6] Soekidjo Notoatmodjo, "Prinsip-Prinsip Dasar Ilmu Kesehatan Masyarakat”. $2^{\text {nd }}$ ed, Rineka Cipta, Jakarta, 2003, pp 97-102

[7] Departemen Kesehatan, "Peraturan Menteri Kesehatan Republik Indonesia no 3 tahun 2020 tentang Klasifikasi dan Perizinan Rumah Sakit”, Departemen Kesehatan, 2020, https://jdihn.go.id/search/pusat/detail/1043731

[8] N.M. Samsuddin, R. Takim, A. H. Nawawi., M.R. Rosman., dan S.N.A. SyedAlwee, "Non-structural Components influencing Hospital Disaster Preparedness in Malaysia", OP Conference Series: Earth and Environmental Science, Volume 140, 4th International Conference on Civil and Environmental Engineering for Sustainability (IConCEES), Langkawi, Malaysia, December, 2017, Vol 140 012007, pp. 1-10, doi :10.1088/1755-1315/140/1/012007

[9] George. C. Yao \& Chi - Chang Lin, "Identification Of Earthquake Damaged Operational And Functional Components In Hospital Buildings", Journal of the Chinese Institute of Engineers, Vol 23, Issue 4, 409-416. 2000, doi: https://doi.org/10.1080/02533839.2000.9670561

[10] Chiara Casarotti, dan Alberto Pavese, dan Simone Peloso, "Seismic Response of the San Salvatore Hospital of Coppito (L'Aquila) During the 6th April 2009 Earthquake", Progettazione Sismica, 3, pp. 163-176. 2009

[11] World Health Organization \& Pan American Health Organization, "Hospital safety index: guide for evaluators", $2^{\text {nd }}$ ed. World Health Organization, 2015, https://apps.who.int/iris/handle/10665/258966

[12] Mansur Hamma-Adama."Causes of Building Failure And Collapse In Nigeria: Professionals View." American Journal of Engineering Research (AJER), vol. 6, no. 12, 2017, pp. 289-300. 2017

[13] Bungale. S. Taranath, "Wind and Earthquake Resistant Buildings Structural Analysis and Design”, $10^{\text {th }}$, Marcel Dekker, New Jersey, 2005

[14] Avadhoot. S. Bhosale, Robin Davis, and Pradip Sarkar, "Seismic Safety of Vertically Irregular Buildings: Performance of Existing Indicators", Journal of Architectural Engineering, ASCE, 24, 04018013-1 04018013-9, 2018, doi: https://doi.org/10.1061/(ASCE)AE $.1943-5568.0000319$

[15] A. Supriatna, and Purwanto, Kajian Struktur Gedung Tahan Gempa Dengan Berbasis Kinerja Pada Proyek Pembangunan Gedung IA KPMKT Kalimantan Timur Kota 
Samarinda, Jurnal Teknik Sipil dan Arsitektur, Untag Samarinda, Vol 1, No 1, 1-19, 2018

[16] Karel. A. van Laarhoven, Hendrik. P. Huinink, and Olaf. C.G. Adan, "A Microscopy Study of Hyphal Growth of Penicillium Rubens on Gypsum Under Dynamic Humidity Conditions", Microbial Technology, Vol 9, Issue 3, pp. 408-418, 2016, https://doi.org/10.1111/1751-7915.12357

[17] M. Bekker, S.J.F. Erich, S.P.M Hermanns, M.P.F.H.L. van Maris, H.P. Huinink, and O.C.G. Adan, Quantifying Discoloration Caused by The Indoor Fungus Penicillium Rubens on Building Material at Controlled Humidity. Build Environ, Vol 90, 60-70, 2015, doi: https://doi.org/10.1016/j.buildenv.2015.03.020

[18] T. Winarsih, “Asesmen Struktur Bangunan Gedung, Studi Kasus Bangunan Gedung Unit Gawat Darurat (UGD) dan Administrasi Rumah Sakit Umum Daerah Banyudono Kabupaten Boyolali”, Tesis Program Pascasarjana Teknik Rehabilitasi dan Pemeliharaan Bangunan Sipil, (Doctoral Thesis Universitas Sebelas Maret, 2010), retrieved from https://core.ac.uk/download/pdf/12352087.pdf

[19] Nidaa. A. Bajow and Shahnaz. M. Alkhalil, "Evaluation and Analysis of Hospital Disaster Preparedness in Jeddah", Scientific Research, Health, 6, 2668-2687, 2014, http://dx.doi.org/10.4236/health.2014.619306

[20] Eduardo Miranda, Gillberto Mosqueda, Rodrigo Retamales, "Performance of Non-structural Components during the 27 February 2010 Chile Earthquake", Earthquake Spectra, Vol 28, Issue 1, pages S453-S471, 2012, https://doi.org/10.1193/1.4000032

[21] Judith Mitrani-Reiser, Michael Mahoney, William T. Holmes, J. Carlos de la Llera, R. Bissell, and T. Kirsch, “A Functional Loss Assessment of a Hospital System in the Bío-Bío Province", Earthquake Spectra, Vol 28, Issue 1, S473-S502, 2012, https://doi.org/10.1193/1.4000044

[22] Mauro Dolce, Andreas Kappos, Angelo Masi, Gregory Penelis, Marco Vona, "Vulnerability Assessment and Earthquake Damage Scenarios od The Building Stock of Potenza (Southern Italy) Using Italian and Greek Methodologies", Engineering Structures, 28, 375-371, 2006, doi:10.1016/j.engstruct.2005.08.009

[23] Faiz Sathi Abdullah, "Mass Media Discourse: A Critical Analysis Research Agenda", Pertanika Journals, Social Sciences And Humanities, 22 (S) Feb, 1-16, 2014
[24] Emi Sahmeni, and Nur Afifah, "Using Critical Discourse Analysis (CDA) in Media Discourse Studies: Unmask the Mass Media", Journal of Research and Innovation in Language. Vol 1, No 2, 38-45, 2019, doi: https://doi.org/10.31849/reila.v1i2.2764

[25] Matthew David Catton, Ralf Barkemeyer, Barbara Renzi, Guilio Napolitano, "Fracking and Metaphor: Analysing Newspaper Discourse in the USA, Australia and the United Kingdom”, Ecological Economics, 166, 1-12, 2019, doi: https://doi.org/10.1016/j.ecolecon.2019.106426

[26] Ade Gustia Putri, "Discourse in Mass Media: A Study of Critical Analysis Research Agenda", Journal of English Teaching and Research, Vol 3, No 1, 40-51, 2018, https://doi.org/10.29407/jetar.v3i1.11847

[27] Hanson E. Kusuma, “Analisis Isi, Analisis Data Teks secara Kualitatif dan Kuantitatif", Available from Ikatan Peneliti Lingkungan Binaan Indonesia (IPLBI) to Workshop "Analisis Isi, Analisis Data Teks secara Kualitatif dan Kuantitatif” Participant, Bandung, 2018

[28] John E. Richardson, "Analysing Newspapers an Approach from Critical Discourse Analysis", 16 ${ }^{\text {th }}$, Palgrave Macmillan, New York, 2007

[29] José Barranco, D. Wisler, "Validity and Systematicity of Newspaper Data in Event Analysis", European Sociological Review, Vol 15, No 3, 301-322, 1999, https://www.jstor.or $\mathrm{g} /$ stable/522733

[30] B. Sakina, Hanson E. Kusuma, "Korespondensi Antara Kualitas Hunian Sewa dan Tingkat Kepuasan Mahasiswa", Proceeding Temu Ilmiah IPLBI, 30-31 Oktober 2015, pp. C43-C50, Ikatan Peneliti Lingkungan Binaan Indonesia (IPLBI).

[31] Sari Farlianti, and Sapta Sapta, "Perhitungan Respon Spektra Percepatan Gempa Kota Palembang berdasarkan SNI 1726; 2019 Sebagai Terhadap Revisi SNI 1726;2012”, Jurnal Ilmiah Teknika, Vol 6, No 2, pp. 167-177, 2017, http://orcid.org/0000-0001-9512-5778

[32] S. Kishore Kumar and P. Sriram, Pivotal Factors Causing Defects in Buildings: A Case Study in Chennai, Tamil Nadu, International Journal of Civil Engineering and Technology (IJCIET), Vol 8, Issue 4, 2017, pp.325-331, http://www.iaeme.com/IJCIET/issues.asp?JType=IJCIET $\&$ VType $=8 \&$ IType $=4$ 